PRELIMINARY INTERPRETIVE REPORT 2015-7

\title{
OIL-STAINED SANDSTONE IN THE MIDDLE JURASSIC LOWER PAVELOFF SILTSTONE MEMBER OF THE CHINITNA FORMATION: EXPLORING THE POTENTIAL ROLE OF FACIES VARIATIONS IN CONTROLLING DIAGENESIS AND RESERVOIR QUALITY IN WESTERN COOK INLET, ALASKA
}

by

Marwan A. Wartes and Trystan M. Herriott

December 2015

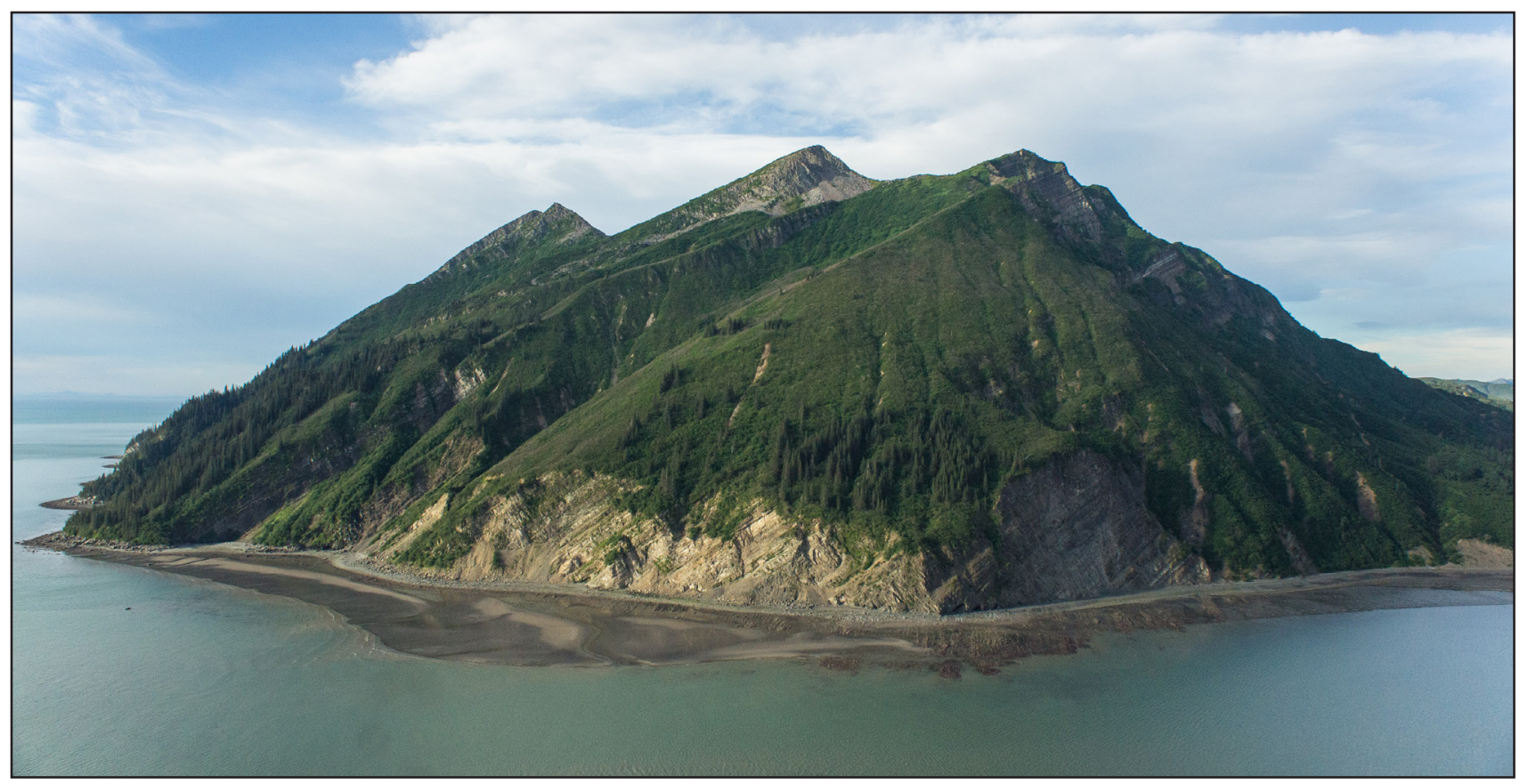

Oblique aerial view southward of the south shore of Chinitna Bay near Cook Inlet (at left of photograph). Excellent exposures of Mesozoic Cook Inlet forearc basin strata occur along this coast, with the Middle Jurassic Paveloff Siltstone Member (Chinitna Formation) chiefly cropping out in the shadowed sea cliff at right of photograph. The oil-stained sandstone locality of this study is near the base of the Paveloff in the area where brush extends down to the beach. Photograph by T.M. Herriott.

\author{
Released by \\ STATE OF ALASKA \\ DEPARTMENT OF NATURAL RESOURCES \\ Division of Geological \& Geophysical Surveys
}

$\$ 2.00$ 



\title{
OIL-STAINED SANDSTONE IN THE MIDDLE JURASSIC LOWER PAVELOFF SILTSTONE MEMBER OF THE CHINITNA FORMATION: EXPLORING THE POTENTIAL ROLE OF FACIES VARIATIONS IN CONTROLLING DIAGENESIS AND RESERVOIR QUALITY IN WESTERN COOK INLET, ALASKA
}

\author{
by \\ Marwan A. Wartes ${ }^{1}$ and Trystan M. Herriott ${ }^{1}$
}

\section{INTRODUCTION}

The oil produced from Cook Inlet basin has almost exclusively come from Cenozoic reservoirs (for example, Magoon, 1994). The potential for additional reservoirs in underlying Middle and Upper Jurassic strata is poorly known and essentially untested by exploration drilling (LePain and others, 2013), despite the fact that the inferred oil source rocks lie at the base of the Middle Jurassic section (Magoon and Anders, 1992). The principal risk recognized for the Middle and Upper Jurassic sandstones is the presence of adequate reservoir quality; most existing data indicate low porosity and permeability (Lyle and Morehouse, 1977; Magoon, 1986; Helmold and others, 2013). The primary features compromising reservoir quality include compaction of ductile grains and the development of laumontite cement (McLean, 1979; 1986; Franks and Hite, 1980; Bolm and McCulloh, 1986; Helmold and others, 2013). Both of these characteristics are typical of forearc basins and reflect the primary magmatic arc provenance, which produced abundant volcanic rock fragments and feldspar during progressive unroofing (Detterman and Hartsock, 1966; Lankford and Magoon, 1978; Magoon and Egbert, 1986; Egbert, 1986; Hudson, 1986).

An economically viable Jurassic-hosted petroleum system in Cook Inlet is unproven, but pending additional exploration, continues to warrant consideration in assessments of the basin's ultimate hydrocarbon potential (Decker and DGGS staff, 2006; Stanley and others, 2011). In particular, data from the Iniskin Peninsula of western Cook Inlet (fig. 1) suggest the Jurassic section may have potential as an unconventional fractured reservoir, based on surface seeps associated with faults, oil-stained fault zones in outcrop, and hydrocarbon shows encountered in faulted and fractured zones intersected by exploration wells (Detterman and Hartsock, 1966; Wartes and Herriott, 2014a). Evidence for hydrocarbons in non-fracture pore space of Jurassic rocks is more limited, although several authors have noted an important Upper Jurassic locality near the mouth of the Douglas River along the south shore of Kamishak Bay (Magoon and others, 1975; Lyle and Morehouse, 1977; Helmold, 2013; Stanley and others, 2013; Herriott and others, 2013). In addition, the COST No. 1 well encountered a number of minor oil shows in the Upper Jurassic (Magoon, 1986).

The purpose of this report is to offer additional description and interpretation of an occurrence of oil-stained Jurassic rocks on the Iniskin Peninsula, first noted by Wartes and Herriott (2014b). These rocks are not fractured, suggesting the hydrocarbons are hosted in matrix porosity. This raises the possibility that processes inhibiting reservoir quality are not omnipresent in Cook Inlet, but instead may vary depending on sedimentary facies.

\section{FACIES AND OCCURRENCE OF OIL STAIN}

A new locality ${ }^{2}$ of oil-stained Jurassic rocks was discovered during a geologic mapping traverse along the south shore of Chinitna Bay (fig. 1; see project overview in Gillis and others, 2014). The outcrop is part of an east-dipping succession that includes the Middle Jurassic Chinitna Formation and much of the Upper Jurassic Naknek Formation (fig. 1). The excellent sea-cliff exposures can be correlated southward into the Tilted Hills (figs. 2 and 3; Herriott and Wartes, 2014).

The oil-stained interval is in an approximately 100-m-thick sandstone-dominated package mapped as the lower part of the Paveloff Siltstone Member of the Chinitna Formation (figs. 1-3). Recent geologic mapping by Herriott and Wartes (2014) is broadly in agreement with existing map unit criteria laid out in Detterman and Hartsock (1966), particularly the recognition of a locally developed, sandstone-rich facies in the basal Paveloff Siltstone.

The environment of deposition for the Paveloff Siltstone has not been studied in detail ${ }^{3}$, but abundant megafossil collections suggest it is entirely marine (Detterman and Hartsock, 1966). LePain and others (2013) described the basal sandstone

\footnotetext{
${ }^{1}$ Alaska Division of Geological \& Geophysical Surveys, 3354 College Rd., Fairbanks, AK 99709-3707; marwan.wartes@alaska.gov; trystan.herriott@alaska.gov

${ }^{2}$ Location coordinates: N59.83472 ${ }^{\circ}$; W153.01906 (NAD27AK)

${ }^{3} \mathrm{~A}$ detailed section of the Paveloff Siltstone was measured along the east shore of Oil Bay in 2013 by Rick Stanley (U.S. Geological Survey) and Ken Helmold (Alaska Division of Oil and Gas). Publication of their detailed facies analysis and interpretations should improve our understanding of the depositional environment.
} 
interval as regressive, with the upsection transition to more silty lithofacies representing a transgressive succession, likely in a shelfal setting. Deposition on the shelf is consistent with isolated observations during mapping that document common trace fossils such as Phycosiphon and structureless beds that are interpreted to reflect thorough bioturbation (Herriott and Wartes, 2014). Examination of more than 30 samples from the Paveloff Siltstone documented the presence of dinoflagellates and both terrestrial and marine palynomorphs, which is consistent with a marine setting, likely proximal to a delta (P. Zippi, unpublished 2014 DGGS report).

The moderate to strong hydrocarbon odor was discovered in a sandstone boulder at the base of the outcrop (figs. 3 and 4). Adjacent outcrops of the same lithofacies (background of fig. 4) also exhibit minor oil stain and may have rotated slightly during slumping. All oil-stained rocks are clearly derived from the adjacent cliff where in-place exposures of the correlative zone are partially covered by vegetation. The petroliferous zone is a gray-green- to gray-brown-weathering, very-thickbedded, structureless, lithic-rich, coarse-grained sandstone. The unit is poorly sorted and commonly includes randomly distributed granules. The lack of apparent intra-bed grading or stratification indicates non-turbulent flow, and the poor sorting suggests high sediment concentration and low dispersive pressure (Nemec and Steel, 1984). The facies are interpreted as amalgamated subaqueous mass flows, possibly on a delta front characterized by high sediment supply.

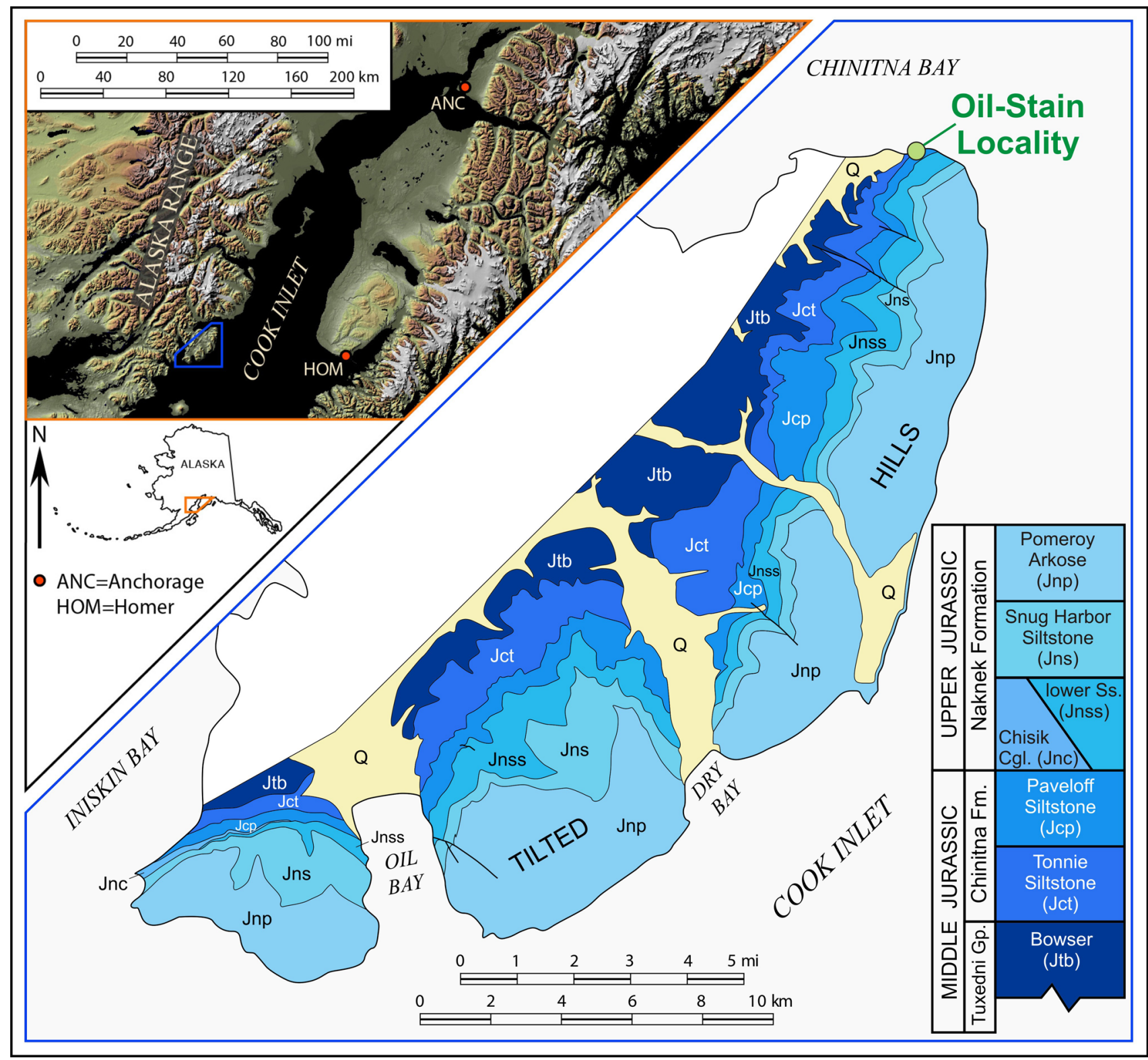

Figure 1. Shaded relief location map of southern Alaska (upper left) and simplified geologic map of the Tilted Hills on the Iniskin Peninsula (modified from Herriott and Wartes, 2014). Note the location of the oil-stained outcrop discussed in this study. Simplified stratigraphic column (lower right) is modified from Detterman and Hartsock (1966). 

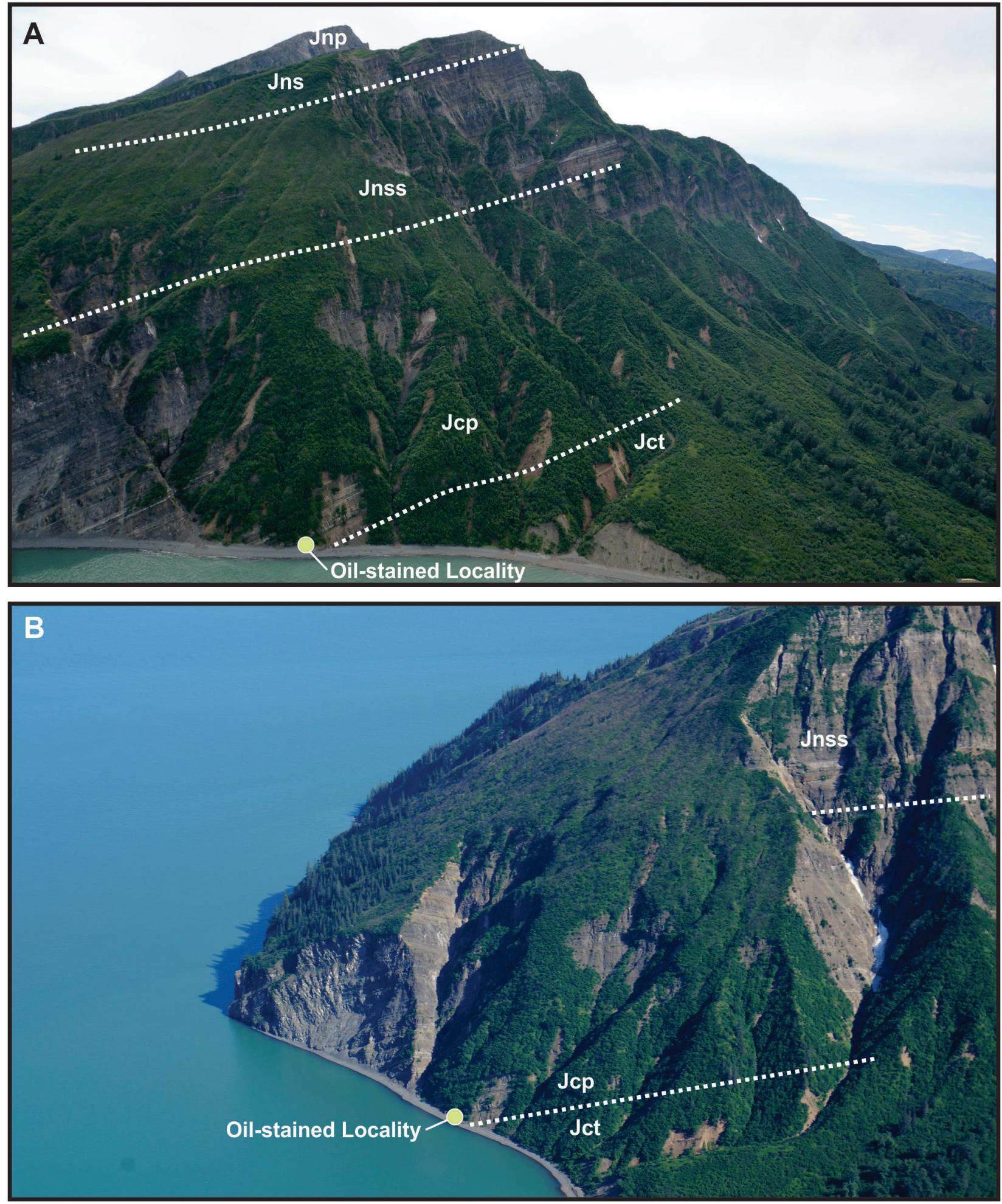

Figure 2. Annotated photos of the northern Tilted Hills on the Iniskin Peninsula. (A) View to the south, with the south shore of Chinitna Bay in the foreground. (B) View to the southeast, with Chinitna Bay in the foreground and Cook Inlet in the background. Unit abbreviations for Members of the Chinitna Formation: Jct = Tonnie Siltstone, Jcp = Paveloff Siltstone;Mmembers of the Naknek Formation: Jnss = lower sandstone, Jns = Snug Harbor Siltstone, Jnp = Pomeroy Arkose. 

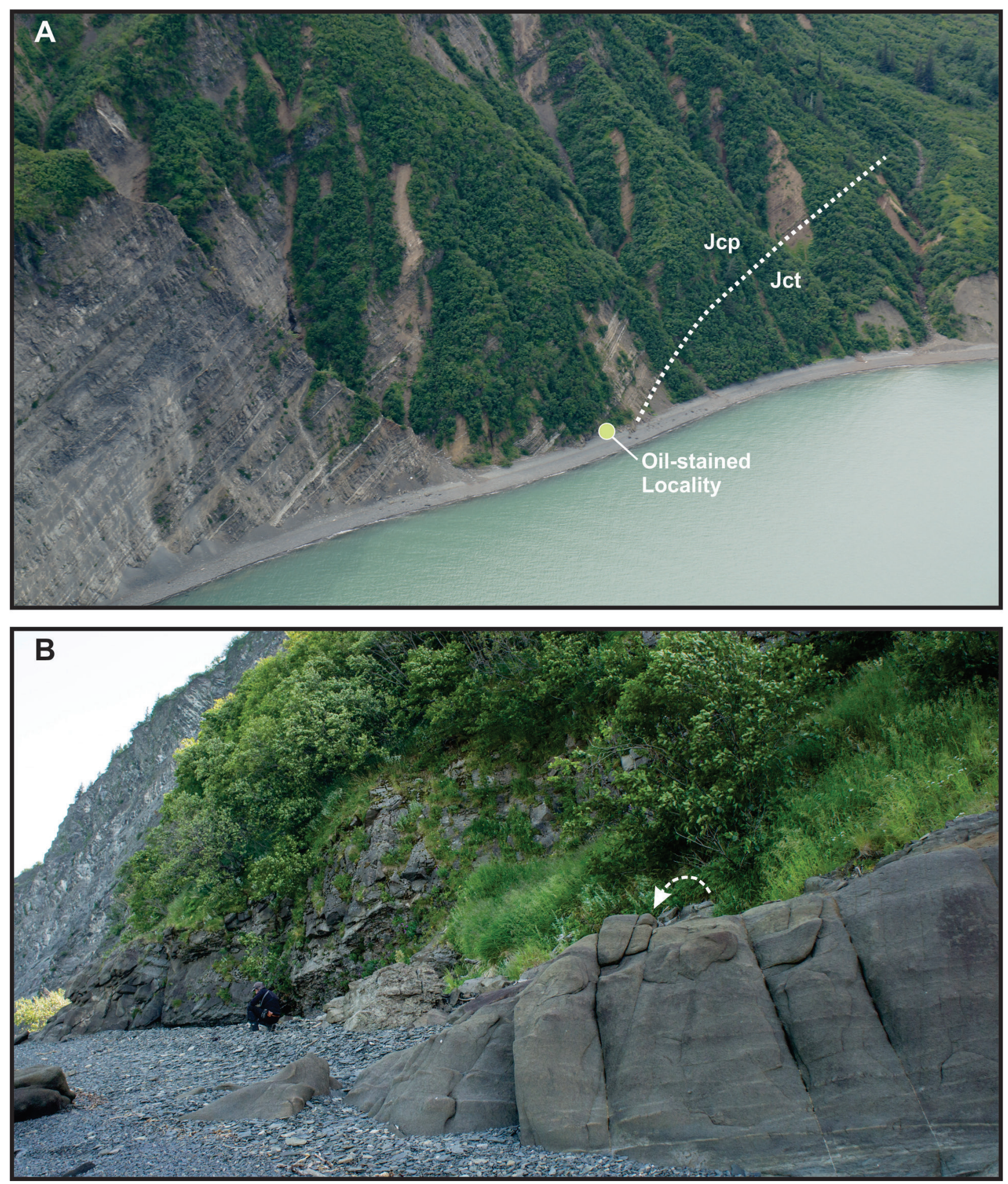

Figure 3. Annotated photos of the oil-stained locality discussed in the text. (A) View to the southwest, illustrating the approximate mapped position of the contact between the Tonnie Siltstone (Jct) and Paveloff Siltstone (Jcp) Members of the Chinitna Formation. (B) Outcrop view with white arrow pointing to the location of the oil-stained zone, which is obscured in this view by the thick sandstone bed in the foreground. 
Samples of the oil-stained sandstone (fig. 4) have been plugged for routine porosity and permeability analysis. Thin sections cut from these cores are currently being evaluated for framework composition, sorting, and cements, following the protocols established in Helmold and others (2013). Samples collected for organic geochemistry have been shipped to the U.S. Geological Survey's organic geochemistry laboratory and await analysis; any extracted hydrocarbons will be compared against data from proposed source rocks (Magoon and Anders, 1992). Results from these follow-up studies will be published in subsequent reports.

\section{DISCUSSION OF APPARENT RESERVOIR QUALITY VARIATIONS}

A number of petrographic investigations of Jurassic rocks in Cook Inlet have demonstrated that the primary reservoir quality challenge is the pervasive alteration and zeolite cementation (McLean, 1979, 1986; Franks and Hite, 1980; Bolm and McCulloh, 1986; Helmold and others, 2013). The abundance of calcic plagioclase and volcanic rock fragments promote cementation by laumontite and heulandite, respectively (for example, Helmold and others, 2013). The formation of zeolites is generally well understood, although the suggested parameters controlling diagenesis indicate a complex process influenced by parent rock composition, temperature, pore fluid chemistry, relative fluid pressure, permeability, and pore fluid throughput (Boles and Coombs, 1977; Helmold and van de Kamp, 1984).

Several scenarios have been suggested that might mitigate the destruction of porosity and permeability in Jurassic sandstones and improve their potential as an exploration target in Cook Inlet. Bolm and McCulloh (1986) suggested that the laumontite diagenetic front may crosscut stratigraphy, particularly if parts of the forearc basin experienced different thermal gradients through time. The relatively limited sampling of Jurassic sandstone, particularly in the subsurface, allows for possible temporal or spatial variations in modal composition. For example, Helmold (2013) noted a more mature, quartzose mineralogy in outcrops of Jurassic sandstone along Kamishak Bay, which would be less prone to zeolite alteration and cementation. Finally, an early phase of hydrocarbon charge has been proposed as a mechanism to retard cementation in Cook Inlet (Bolm and McCulloh, 1986; Helmold, 2013). Although Bolm and McCulloh (1986) offered anecdotal evidence that this process is ineffective in other basins, many studies continue to support the hypothesis that early oil saturation can significantly impede many diagenetic processes (for example, Worden and others, 1998; Bloch and others, 2002).

It is not clear whether a spatially and/or temporally variable geothermal gradient or early oil charge can account for the matrix-hosted oil stain noted in this study. Data available for the Iniskin Peninsula indicate most units have low porosity and permeability, and sandstone beds above the oil-stained interval appear thoroughly impacted by zeolite cementation (Helmold and others, 2013). The timing of source rock maturation in Cook Inlet is also poorly known and likely variable around the basin (LePain and others, 2013). However, the fact that sandstone beds immediately above and below the oil-stained zone are not perceptibly charged suggests they were already cemented prior to local hydrocarbon migration.

An alternate explanation for the occurrence of hydrocarbon saturation observed in this study is suggested by the somewhat unique facies of the oil-bearing bed. The oil-stained interval is more poorly sorted than most sandstone beds in the region, a feature that may have restricted the volume of diagenetic fluids that migrated through the bed. Experiments involving artificially mixed sand have demonstrated that poor sorting results in a predictable decrease in original porosity and permeability (Beard and Weyl, 1973). The lithic-rich, mass flow character of the oil-stained bed may suggest limited winnowing and elevated amounts of argillaceous material, which have been shown to reduce permeability and diagenesis in graywackes, especially if compacted to form pseudomatrix (Loucks and others, 1981).

Original depositional characteristics determine properties such as porosity, permeability, and hydraulic conductivity (for example, Anderson, 1989), and initial facies can clearly impact reservoir quality by directly influencing diagenesis (see review in Morad and others, 2010). A diverse array of studies have concluded that diagenetic fluids will often preferentially flow through zones with higher initial porosity and permeability, leading to the somewhat counterintuitive result that beds with the best original reservoir quality may end up being completely cemented. This phenomenon was well illustrated by Hiatt and others (2003), where examination of the paragenetic sequence of a Precambrian fluvial succession indicated that Uranium-mineralizing fluids did not precipitate in the mineralogically and texturally mature zones, which were already preferentially occluded by earlier phases of cementation. In deep marine sediment gravity flows, well-sorted quartz arenite beds are sometimes preferentially cemented, whereas associated poorly sorted debris flows retain viable reservoir quality (Morris and others, 1979). In carbonate systems, there are many examples in which well-sorted grainstone facies are preferentially cemented (for example, Prior and others, 1995). In addition, the distribution of carbonate concretionary beds are generally regarded as a reflection of permeability anisotropy (Morad and others, 2000).

Other sandstone beds in the lower Paveloff Siltstone are likely cemented by laumontite, based on the light gray color typical of weathered exposures (fig. 3A). However, this visible cementation is not conspicuous in every bed, and in the overlying Naknek Formation locally gives a striped or color-banded character to the outcrops (Herriott and Wartes, 2014). 


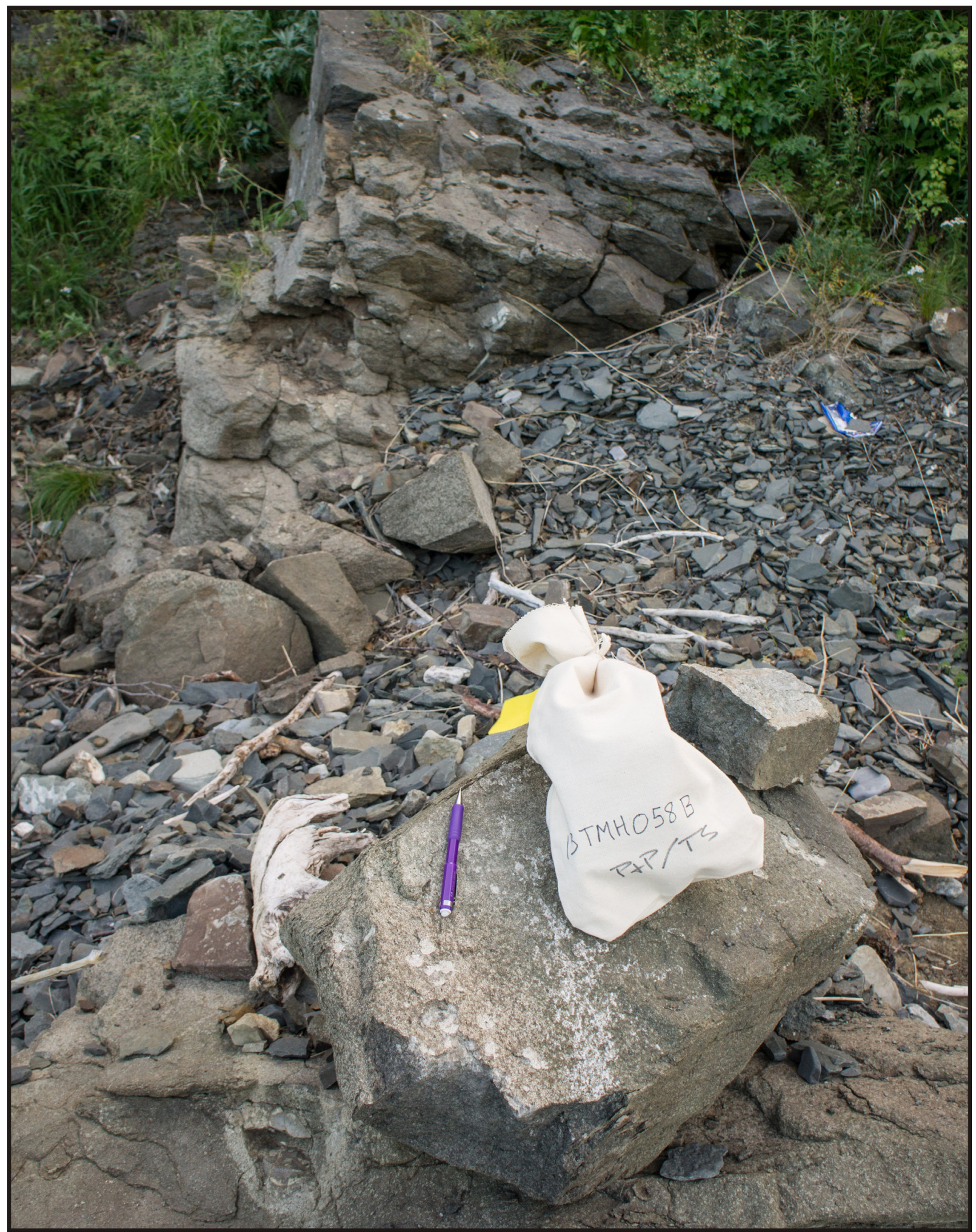

Figure 4. Close-up photo of the oil-stained boulder (note freshly broken surface where sample material was collected). Outcrop in the background also exhibited oil stain, but samples were collected from the related boulder due to a notably stronger petroliferous odor. 
Helmold (2013) speculated this color banding may reflect variations in framework grain composition. However, the lightgray-weathering beds (inferred to be more laumontite rich) appear to occur preferentially in beds that are coarser, better sorted, and lack bioturbation (Wartes and others, 2013). These preliminary observations support the hypothesis that zeolite cementation in the Jurassic section may be highly variable and possibly controlled by original depositional facies that preferentially focused diagenetic fluids in certain beds. Although speculative, this type of highly selective zeolitization has also been observed in volcanic assemblages where the alteration of tuff beds depends not on their chemistry, but rather on whether or not they were welded (non-porous) at deposition (Gibbons and others, 1960).

A comparison of thin-section data from the oil-stained interval with existing information from other samples on the Iniskin Peninsula should provide a test of the hypothesis presented here, namely that facies and depositional texture influenced diagenesis and allowed for the preservation of sufficient non-fracture porosity to host liquid hydrocarbons. Regardless of the ultimate mechanisms controlling reservoir quality in Jurassic strata, this reported discovery of oil-stained sandstone adds to the growing database of hydrocarbon occurrences in Mesozoic rocks of Cook Inlet, furthering the conclusion that much of the region is underlain by a productive source rock. The challenge remains predicting the migration pathways and locating economically significant reservoir facies.

\section{ACKNOWLEDGMENTS}

Funding for this work was provided by the State of Alaska and the National Cooperative Geologic Mapping Program through STATEMAP award number G13AC00157 (administered by the U.S. Geological Survey). Access to lands on the Iniskin Peninsula was generously permitted by Cook Inlet Region, Inc. (CIRI), and the Chickaloon, Knik, Ninilchik, Salamatof, Seldovia, and Tyonek village corporations. We thank the staff at Bear Mountain Lodge for their hospitality. We are grateful to Pathfinder Aviation and helicopter pilot Roger Hinsdale for safely transporting us in the field, often in adverse weather conditions.

This study benefitted from discussions with David LePain, Rick Stanley, Bob Gillis, and Paul Decker. In particular, we thank Ken Helmold for tirelessly educating us on petrology and diagenesis and improving our knowledge of issues affecting reservoir quality in Cook Inlet. Bob Gillis reviewed an early draft of the manuscript; David LePain provided additional helpful review comments.

\section{REFERENCES CITED}

Anderson, M.P., 1989, Hydrogeologic facies models to delineate large-scale spatial trends in glacial and glaciofluvial sediments: Geological Society of America Bulletin, v. 101, no. 4, p. 501-511.

Beard, D.C., and Weyl, P.K., 1973, Influence of texture on porosity and permeability of unconsolidated sand: American Association of Petroleum Geologists Bulletin, v. 57, no. 2, p. 348-369.

Bloch, Salman, Lander, R.H., and Bonnell, Linda, 2002, Anomalously high porosity and permeability in deeply buried sandstone reservoirs-Origin and predictability: American Association of Petroleum Geologists Bulletin, v. 86, no. 2, p. 301-328.

Boles, J.R., and Coombs, D.S., 1977, Zeolite facies alteration of sandstones in the southland syncline, New Zealand: American Journal of Science, v. 277, p. 982-1,012.

Bolm, J.G., and McCulloh, T.H., 1986, Sandstone diagenesis, in Magoon, L.B., ed., Geologic studies of the lower Cook Inlet COST No. 1 well, Alaska outer continental shelf: U.S. Geological Survey Bulletin 1596, p. 51-53.

Decker, P.L., and DGGS Staff, 2006, Alaska GeoSurvey News-A brief overview of Alaska petroleum systems: Alaska Division of Geological \& Geophysical Surveys Newsletter 2006-2, 10 p. doi: $\underline{10.14509 / 15750}$

Detterman, R.L., and Hartsock, J.K., 1966, Geology of the Iniskin-Tuxedni Peninsula region, Alaska: U.S. Geological Survey Professional Paper 512, 78 p., 7 plates.

Egbert, R.M., 1986, Petrography, provenance and tectonic significance of Middle and Upper Jurassic sandstones from Tuxedni Bay, in Magoon, L.B., ed., Geologic studies of the lower Cook Inlet COST No. 1 well, Alaska outer continental shelf: U.S. Geological Survey Bulletin 1596, p. 61-63.

Franks, S.G., and Hite, D.M., 1980, Controls of zeolite cementation in Upper Jurassic sandstone, lower Cook Inlet, Alaska [abs]: American Association of Petroleum Geologists Bulletin, v. 64, p. 708-709.

Gibbons, A.B., Hinrichs, E.N., and Botinelly, T., 1960, The role of impermeable rocks in controlling zeolite alteration of tuff-Geological Survey Research 1960, Short papers in the geological sciences: U.S. Geological Survey Professional Paper 400B, p. B473-B475. 
Gillis, R.J., Wartes, M.A., Herriott, T.M., Bull, K.F., Decker, P.L., and Betka, P.M., 2014, Overview of new 1:63,360-scale geologic mapping of the Iniskin Peninsula, lower Cook Inlet, Alaska, in Gillis, R.J., ed., Cook Inlet program 2013 field studies: Observations and preliminary interpretations from new 1:63,360-scale geologic mapping of the Iniskin Peninsula, lower Cook Inlet, Alaska: Alaska Division of Geological \& Geophysical Surveys Preliminary Interpretive Report 2014-2-1, p. 3-6. doi: $10.14509 / 27306$

Helmold, K.P., 2013, Reservoir quality of sandstones in the Naknek and Kaguyak Formations-Field observations, in Gillis, R.J., ed., Overview of 2012 field studies_-Upper Alaska Peninsula and west side of lower Cook Inlet, Alaska: Alaska Division of Geological \& Geophysical Surveys Preliminary Interpretive Report 2013-1C, p. 11-12. doi:10.14509/24846

Helmold, K.P., and van de Kamp, P.C., 1984, Diagenetic mineralogy and controls on albitization and laumontite formation in Paleogene arkoses, Santa Ynez Mountains, California, in McDonald, D.A., and Surdam, R.C., eds., Clastic diagenesis: American Association of Petroleum Geologists Memoir, v. 37, p. 239-276.

Helmold, K.P., LePain, D.L., Wilson, M.D., and Peterson, C.S., 2013, Petrology and reservoir potential of Tertiary and Mesozoic sandstones, Cook Inlet, Alaska-A preliminary analysis of outcrop samples collected during 2007-2010 field seasons: Alaska Division of Geological \& Geophysical Surveys Preliminary Interpretive Report 2013-5, 34 p. doi: $10.14509 / 25035$

Herriott, T.M., and Wartes, M.A., 2014, Geologic-mapping-based observations of the Middle Jurassic Chinitna Formation and Upper Jurassic Naknek Formation in the Tilted Hills, Iniskin Peninsula, Cook Inlet, Alaska: Alaska Division of Geological \& Geophysical Surveys Preliminary Interpretive Report 2014-3, 23 p. doi:10.14509/27305

Herriott, T.M., Wartes, M.A., Stanley, R.G., Lillis, P.G., Helmold, K.P., Decker, P.L., and Gillis, R.J., 2013, Oil-stained sandstones of the Upper Jurassic Naknek Formation and Upper Cretaceous Kaguyak Formation, Kamishak Bay area, lower Cook Inlet, Alaska [poster]: American Association of Petroleum Geologists Pacific Section Meeting, Monterey, CA.

Hiatt, E.E., Kyser, Kurt, and Dalrymple, R.W., 2003, Relationships among sedimentology, stratigraphy, and diagenesis in the Proterozoic Thelon Basin, Nunavut, Canada-Implications for paleoaquifers and sedimentary-hosted mineral deposits: Journal of Geochemical Exploration, v. 80, no. 2-3, p. 221-240.

Hudson, T.L., 1986, Plutonism and provenance-Implications for sandstone compositions, in Magoon, L.B., ed., Geologic studies of the lower Cook Inlet COST No. 1 well, Alaska Outer Continental Shelf: U.S. Geological Survey Bulletin 1596 , p. 55-60.

Lankford, S.M., and Magoon, L.B., 1978, Petrography of the Upper Jurassic through Oligocene sandstones in the Cape Douglas-Kamishak Hills area, lower Cook Inlet, in Johnson, K.M., ed., The United States Geological Survey in AlaskaAccomplishments during 1977: U.S. Geological Survey Circular 772-B, p. B60-62.

LePain, D.L., Stanley, R.G., Helmold, K.P., and Shellenbaum, D.P., 2013, Geologic framework and petroleum systems of Cook Inlet basin, south-central Alaska, in Stone, D.M., and Hite, D.M., eds., Oil and gas fields of the Cook Inlet basin, Alaska: American Association of Petroleum Geologists Memoir 104, p. 37-116.

Loucks, R.G., Richmann, D.L., and Milliken, K.L., 1981, Factors controlling reservoir quality in Tertiary sandstones and their significance to geopressured geothermal production: Bureau of Economic Geology, University of Texas at Austin, Report of Investigations 111, $41 \mathrm{p}$.

Lyle, W.M., and Morehouse, J.A., 1977, Physical parameters of potential petroleum reservoir and source rocks in the Kamishak-Iniskin-Tuxedni region, lower Cook Inlet: Alaska Division of Geological \& Geophysical Surveys Alaska Open-File Report 104, 79 p., 13 sheets, scale 1:250,000. doi:10.14509/9

Magoon, L.B., 1986, Stratigraphic units of the COST No. 1 well, in Magoon, L.B., ed., Geologic Studies of the Lower Cook Inlet COST No. 1 well, Alaska Outer Continental Shelf: U.S. Geological Survey Bulletin 1596, p. 17-22.

Magoon, L.B., 1994, Tuxedni-Hemlock(!) petroleum system in Cook Inlet, Alaska, U.S.A., in Magoon, L.B., and Dow, W.G., eds., The petroleum system-From source to trap: American Association of Petroleum Geologists Memoir 60, p. 359-370.

Magoon, L.B., and Anders, D.E., 1992, Oil-to-source-rock correlation using carbon-isotopic data and biological marker compounds, Cook Inlet-Alaska Peninsula, Alaska, in Moldowan, J.M., Albrecht, Pierre, and Philp, R.P., eds., Biological markers in sediments and petroleum: Englewood Cliffs, N.J., Prentice-Hall, p. 241-274.

Magoon, L.B., and Egbert, R.M., 1986, Framework geology and sandstone composition, in Magoon, L.B., ed., Geologic studies of the lower Cook Inlet COST No. 1 well, Alaska Outer Continental Shelf: U.S. Geological Survey Bulletin 1596, p. 65-90. 
Magoon, L.B., Hampton, M.A., Sable, E.G., Smith, R.A., and Chmelik, F.B., 1975, Hydrocarbon potential, geologic hazards, and the technology, time-frame, and infrastructure for exploration and development of the lower Cook Inlet, Alaska-A preliminary assessment: U.S. Geological Survey Open-File Report 75-549, 74 p.

McLean, H., 1979, Sandstone petrology_Upper Jurassic Naknek Formation of the Alaska Peninsula and coeval rocks on the Bering Shelf: Journal of Sedimentary Petrology, v. 49, p. 1,263-1,267.

McLean, H., 1986, Sandstone petrography, in Magoon, L.B., ed., Geologic studies of the lower Cook Inlet COST No. 1 well, Alaska Outer Continental Shelf: U.S. Geological Survey Bulletin 1596, p. 47-49.

Morad, S., Ketzer, J.M., and De Ros, L.F., 2000, Spatial and temporal distribution of diagenetic alterations in siliciclastic rocks-Implications for mass transfer in sedimentary basins: Sedimentology, v. 47, p. 95-120.

Morad, S., Al-Ramadan, Khalid, Ketzer, J.M., and De Ros, L.F., 2010, The impact of diagenesis on the heterogeneity of sandstone reservoirs-A review of the role of depositional facies and sequence stratigraphy: American Association of Petroleum Geologists Bulletin, v. 94, no. 8, p. 1,267-1,309.

Morris, R.C., Proctor, K.E., and Koch, M.R., 1979, Petrology and diagenesis of deep-water sandstones, Ouachita Mountains, Arkansas and Oklahoma, in Scholle, P.A., and Schluger, P.R., eds., Aspects of Diagenesis: SEPM Special Publication No. 26, p. 263-279.

Nemec, W., and Steel, R.J., 1984, Alluvial and coastal conglomerates-Their significant features and some comments on gravelly mass-flow deposits, in Koster, E.H., and Steel, R.J., eds., Sedimentology of gravels and conglomerates: Canadian Society of Petroleum Geologists Memoir, v. 10, p. 1-31.

Prior, D.J., Marsaglia, K.M., Rochford, E.L., Agar, S.M., and Coy, G., 1995, Textural evidence of diagenetic evolution at site 863, Chile Triple Junction, in Lewis, S.D., Behrmann, J.H., Musgrave, R.J., and Cande, S.C., eds., Proceedings of the Ocean Drilling Program: Scientific Results, v. 141, p. 153-167.

Stanley, R.G., Herriott, T.M., Helmold, K.P., Gillis, R.J., and Lillis, P.G., 2013, Hydrocarbon-bearing sandstone in the Upper Jurassic Naknek Formation on the south shore of Kamishak Bay, in Gillis, R.J., ed., Overview of 2012 field studies-Upper Alaska Peninsula and west side of lower Cook Inlet, Alaska: Alaska Division of Geological \& Geophysical Surveys Preliminary Interpretive Report 2013-1E, p. 19-23. doi:10.14509/24848

Stanley, R.G., Pierce, B.S., and Houseknecht, D.W., 2011, U.S. Geological Survey 2011 assessment of undiscovered oil and gas resources of the Cook Inlet region, south-central Alaska: U.S. Geological Survey Open-File Report 2011-1137, 37 p.

Wartes, M.A., and Herriott, T.M., 2014a, A new occurrence of oil-stained rocks within a small fault zone involving the Middle Jurassic Cynthia Falls Formation, Tuxedni Group, northern Iniskin Peninsula, in Gillis, R.J., ed., Cook Inlet program 2013 field studies_-Observations and preliminary interpretations from new 1:63,360-scale geologic mapping of the Iniskin Peninsula, lower Cook Inlet, Alaska: Alaska Division of Geological \& Geophysical Surveys Preliminary Interpretive Report 2014-2-5, p. 23-27. doi:10.14509/27310

Wartes, M.A., and Herriott, T.M., 2014b, Discovery of oil-stained sandstone within the Chinitna Formation, northern Iniskin Peninsula, in Gillis, R.J., ed., Cook Inlet program 2013 field studies - Observations and preliminary interpretations from new 1:63,360-scale geologic mapping of the Iniskin Peninsula, lower Cook Inlet, Alaska: Alaska Division of Geological \& Geophysical Surveys Preliminary Interpretive Report 2014-2-6, p. 29-31. doi:10.14509/27311

Wartes, M.A., Herriott, T.M., Helmold, K.P., and Gillis, R.J., 2013, Preliminary stratigraphic interpretation of the Naknek Formation-Evidence for Late Jurassic activity on the Bruin Bay fault, Iniskin Peninsula, lower Cook Inlet, in Gillis, R.J., ed., Overview of 2012 field studies_-Upper Alaska Peninsula and west side of lower Cook Inlet, Alaska: Alaska Division of Geological \& Geophysical Surveys Preliminary Interpretive Report 2013-1H, p. 39-46. doi:10.14509/24851

Worden, R.H., Oxtoby, N.H., and Smalley, P.C., 1998, Can oil emplacement prevent quartz cementation in sandstones?: Petroleum Geoscience, v. 4, p. 129-137. 